\title{
Microbial Quality and Storage Stability of Millet Based High Fiber Food Mix
}

\author{
K. Geetha, Geetha M. Yankanchi and Netravati Hiremath*
}

\author{
All India Coordinated Research Project on Foods and Nutrition, University of Agricultural \\ Sciences, GKVK, Bengaluru, Karnataka, India
}

*Corresponding author

\section{A B S T R A C T}

Food safety evaluation and storage stability of developed mix or food products is an essential criterion to safeguard the public health and provides assurance on food safety.

\section{Keywords}

Microbial quality, Storage stability, Millet

\section{Article Info}

Accepted: 04 June 2019 Available Online: 10 July 2019 Hence the present study was undertaken with an objective to evaluate the millet based high fiber food mix for their microbial quality and storage stability. The high fiber food mix was developed by using region specific ingredients. It was revealed that, as the storage period increased, there was increase in moisture, free fatty acid and peroxide values at different storage period $(0,15,30,45,60,75$ and 90 days of storage). The per cent free fatty acid content in high fiber mix ranged from $2.31 \pm 0.12$ to $4.83 \pm 0.09$ as oleic acid measure and was in acceptable range. A steady and significant increase in peroxide value was evident as the storage period proceeded $\left(0.71 \pm 0.06 \mathrm{mEq} \mathrm{O}_{2} / \mathrm{kg}\right.$ to $3.61 \pm 0.05 \mathrm{mEq}$ $\mathrm{O}_{2} / \mathrm{kg}$ of extracted fat). Developed mix recorded increasing trend in total bacterial count as the storage period increased. Presence of mold was noticed at the storage period of 75 and 90 days and E-coli was absent throughout the storage period. However, it is in the permissible limit. High fibre food mix prepared from locally available ingredients showed the acceptable storage stability for 90 days. For further shelf life enhancement, it is essential to adopt a new packaging technique as well as innovative technologies.

\section{Introduction}

Over the past decades, dietary fibre (DF) has gained more importance in nutritional area due to its abundant health benefits. Several epidemiological studies also indicated an inverse relationship between dietary fiber intake and decline in weight (Koh et al., 2003; Slavin, 2005) and are strongly supported by cross-sectional studies. It has also great role in the management of cardiovascular diseases, blood sugar, digestive and general illness.
Fiber has been ranked number five among the top functional food concepts (Solan, 2008). However, researchers have reported the decreased intake of dietary fiber; even the amount is so far below than the recommended level. Millets being rich source of dietary fibre needs to be explored for the positive nutritional benefits to popularize them among all sectors of the society to achieve the nutritional security. The millets in combination with pulses, vegetables and spices can be utilized to develop high fibre 
food mix. Development of high fibre food products for effective health benefits is the need of society. At the same time food safety evaluation and storage stability of developed mix or food products is an essential criterion. This safeguards public health and provides assurance on food safety. To this end, microbiological analyses are useful ways to assess the safety and quality of foods involved. Hence the present study was undertaken with an objective to evaluate the millet based high fiber food mix for their microbial quality and storage stability.

\section{Materials and Methods}

\section{Development of millet based mix}

Locally grown region specific millets, pulses, vegetables and some of the functional foods were identified for development of high fibre food mix. Millet based food mix was prepared by using the identified ingredients viz., finger millet (Eleusine coracana), little millet (Panicum sumatrense), defatted soya (Glycine max) flour, whole green gram (Vigna radiata), fenugreek seeds (Trigonellafoenum-graecum), cluster bean (Cyamopsis tetragonoloba), drumstick leaves (Moringa oleifera) and curry leaves (Murraya koinigii) at definite proportion. All the ingredients used for the study were procured from local market of Bengaluru. Fresh cluster beans, drumstick and curry leaves were washed thoroughly, blanched for one minute and oven dried and made into flour. Further finger millet, little millet and whole green gram and fenugreek seeds were cleaned and made into flour. Millet based mix was prepared by mixing thoroughly the flours, dehydrated vegetable flour and defatted soya flour as shown in Figure 1. Developed mix was stored in low density polyethylene (350 gauge) cover for further quality assessment. Moisture, peroxide value, free fatty acid contents and microbial quality were analyzed at initial stage and throughout the storage period at the fifteen days of interval that is at $0,15,30,45$ and 60 and $90^{\text {th }}$ day of storage.

\section{Moisture}

Moisture was determined by taking about $10 \mathrm{~g}$ of sample in petri dish and dried in an oven at $105^{\circ} \mathrm{C}$ till the weight of the petri dish with its content was constant. Each time before weighing, the petri dish was cooled in desiccator. Moisture content of the sample was expressed in $\mathrm{g} / 100 \mathrm{~g}$ of sample (AOAC, 2000).

\section{Free fatty acids and peroxide value}

Clear oil was extracted was used for both free fatty acid and peroxide value estimation. The free fatty acid content was estimated by following the AOAC, 2003 and peroxide by AOAC, 2000 method

\section{Microbial quality}

Microbial load was assessed by pour plate method (Tate, 1995). Ten grams of each sample (different variations) was mixed in 90 $\mathrm{ml}$ sterile water blank to give $10^{-1}$ dilution. Subsequent dilutions up to $10^{-4}$ were made by transferring serially $1 \mathrm{ml}$ of the dilution to 9 $\mathrm{ml}$ of sterile water blanks. The populations of bacteria, molds and yeasts were estimated by transferring $1 \mathrm{ml}$ of $10^{-2}, 10^{-3}$ and $10^{-4}$ dilutions respectively to a sterile petri dish and approximately $20 \mathrm{ml}$ of media viz., nutrient agar, Martins Rose Bengal Agar and Davis Yeast Extract Agar for bacteria, molds and yeasts respectively were poured into plates. The plates were rotated twice in clockwise and anticlockwise direction for uniform distribution of the inoculums. After solidification of the media, plates were kept for incubation in an inverted position at $30 \pm$ $1^{0} \mathrm{C}$ for two to four days and emerged colonies were counted. 


\section{Statistical analysis}

Data are shown as means with their standard deviations. One way analysis of variance (Ftest) was applied to assess the statistical significance.

\section{Results and Discussion}

Stability of stored millet based high fibre food mix is presented in table 1. At the initial period moisture, free fatty acid and peroxide values showed the content of $9.10 \pm 0.07 \mathrm{~g}$, $2.31 \pm 0.12 \mathrm{~g}$ as oleic acid and $0.71 \pm 0.06$ $\mathrm{mEq}$ per 100 of respectively. It was revealed that, as the storage period increased, there was increase in moisture, free fatty acid and peroxide values at different storage period $(0$, $15,30,45,60,75$ and 90 days of storage). The moisture content in mix ranged from $9.10 \pm$ 0.07 to $11.03 \pm 0.14$ per cent from initial to final storage period of $90^{\text {th }}$ day. This indicates that the packaging needs to be further improved to prevent moisture entry. The increase in moisture content during storage period noticed in the present study is in concurrence with the observation of Shoba $e t$ al., (2011). The per cent free fatty acid content in high fiber mix ranged from $2.31 \pm 0.12$ to $4.83 \pm 0.09$ as oleic acid measure and was in acceptable range. The level of free fatty acid (FFA) is a good measure of the storage conditions of either the grain or the flour (Varsha and Aruna, 2017). A high FFA value is mainly due to hydrolytic changes associated with the action of lipolytic enzymes (Thiam, 1977). A steady and significant increase in peroxide value was evident as the storage period progressed $\left(0.71 \pm 0.06 \mathrm{mEq} \mathrm{O}_{2} / \mathrm{kg}\right.$ to $3.61 \pm 0.05 \mathrm{mEq} \mathrm{O} \mathrm{O}_{2} / \mathrm{kg}$ of extracted fat) and such findings were in well accordance with the results reported by Shaila kurahatti (2010).

The increase in peroxide value might be due to oxidation of unsaturated fatty acids present in mix. Peroxide value is used as an indicator of rancidity development during storage. However, the high fibre mix is stable as the peroxide value was less than $10 \mathrm{mEq} \mathrm{O}_{2} / \mathrm{kg}$. When the peroxide value is between 30 and 40 $\mathrm{mEq} / \mathrm{kg}$, a rancid taste is noticeable (Chakrabarty, 2003). Free fatty acids (FFA) generated in hydrolytic deterioration (rancidity) of triacylglycerols that occurs under unsuitable storage conditions of fats (Koczon et al., 2008).

Table.1 Storage stability of stored millet based high fibre food mix

\begin{tabular}{|c|c|c|c|}
\hline Storage duration (Days) & Moisture (\%) & FFA (\% oleic acid) & PV (mEq $\mathbf{O}_{2} / \mathbf{K g}$ of oil) \\
\hline Initial & $9.10 \pm 0.07$ & $2.31 \pm 0.12$ & $0.71 \pm 0.06$ \\
\hline $\mathbf{1 5}$ days & $9.14 \pm 0.06$ & $2.46 \pm 0.07$ & $0.76 \pm 0.05$ \\
\hline $\mathbf{3 0}$ days & $9.32 \pm 0.04$ & $2.71 \pm 0.12$ & $1.08 \pm 0.05$ \\
\hline $\mathbf{4 5}$ days & $9.46 \pm 0.05$ & $3.04 \pm 0.11$ & $1.78 \pm 0.15$ \\
\hline $\mathbf{6 0}$ days & $9.85 \pm 0.09$ & $3.50 \pm 0.08$ & $2.04 \pm 0.08$ \\
\hline $\mathbf{7 5}$ days & $10.27 \pm 0.06$ & $4.38 \pm 0.23$ & $2.57 \pm 0.10$ \\
\hline $\mathbf{9 0}$ days & $11.03 \pm 0.14$ & $4.83 \pm 0.09$ & $3.61 \pm 0.05$ \\
\hline F value & $*$ & $*$ & $*$ \\
\hline SEm \pm & 0.03 & 0.06 & 0.05 \\
\hline CD @ 5 \% & 0.10 & 0.19 & 0.14 \\
\hline
\end{tabular}

Note: FFA: Free fatty acid 
Table.2 Microbial load of stored millet based high fibre food mix

\begin{tabular}{|c|c|c|c|}
\hline Storage duration (Days) & \multicolumn{3}{|c|}{$\mathbf{1 0}^{\mathbf{3}} \mathbf{C F U / g}$} \\
\cline { 2 - 4 } & Total bacterial count & Mold & E- coli \\
\hline Initial & $3.55 \pm 0.55$ & ND & ND \\
\hline $\mathbf{1 5}$ days & $3.95 \pm 0.55$ & ND & ND \\
\hline 30 days & $5.12 \pm 0.36$ & ND & ND \\
\hline $\mathbf{4 5}$ days & $6.22 \pm 0.30$ & ND & ND \\
\hline 60 days & $8.56 \pm 0.30$ & ND & ND \\
\hline $\mathbf{7 5}$ days & $9.60 \pm 0.37$ & $0.66 \pm 0.58$ & ND \\
\hline $\mathbf{9 0}$ days & $10.97 \pm 0.23$ & $0.66 \pm 0.58$ & ND \\
\hline F value & $*$ & $*$ & - \\
\hline SEm \pm & 0.22 & 0.17 & - \\
\hline CD @ 5 \% & 0.68 & 0.52 & - \\
\hline
\end{tabular}

Note: CFU: Colony forming unit

Fig. 1. Development of millet based high fibre food mix

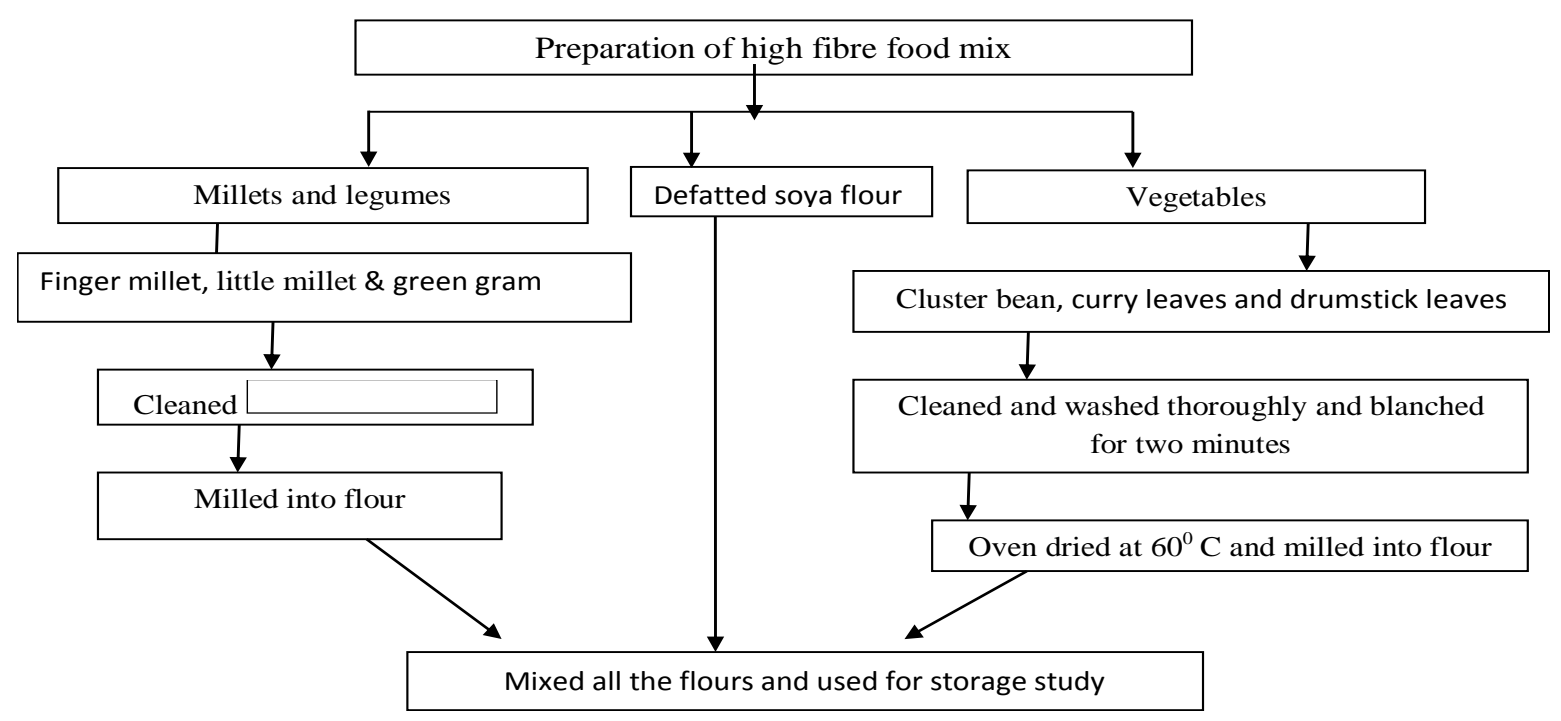

Microbial load of millet based high fibre food mix stored for different storage period is presented in table 2. Developed mix recorded increasing trend in total bacterial count as the storage period increased. Mold presence was observed at the storage period of 75 and 90 days. Escherichia coli was absent throughout the storage period. The range of total bacterial count was $3.55 \pm 0.55$ to $10.97 \pm 0.23\left(\times 10^{3}\right.$ $\mathrm{CFU} / \mathrm{g}$ ) from initial to $90^{\text {th }}$ day of storage. Microbial study becomes an important issue from safety point of view in all food processing and product formulation. Hence the microbial load i.e. total bacterial count, mold and yeast was carried out for the developed high fiber mix for a period of 90 days. The total bacterial count in composite mix comparatively lower than the high fibre mix with the count of $2.2 \times 102 \mathrm{cfu}$ /g at one month storage (Priyanka et al., 2018). However, such incremental trend in bacterial count upon storage for two months was observed by Priyanka et al., (2018).

In conclusion, storage quality of any developed product is a crucial factor to be considered for commercialization. Shelf life study furnishes 
information with regard to keeping quality of the products when packed in a particular packaging material and stored under ambient condition. High fibre food mix prepared from locally available ingredients showed the acceptable storage stability for 90 days. For further shelf life enhancement, it is essential to adopt a new packaging technique as well as innovative technologies.

\section{Acknowledgement}

The research team acknowledges the Indian Council of Agricultural Research (ICAR) Central Institute for Women in Agriculture (CIWA), Government of India and University of Agricultural Sciences, Gandhi Krishi Vigyan Kendra, Bengaluru, Government of Karnataka (GOK) for funding the research.

\section{References}

AOAC (2000), Official Methods of Analysis, $17^{\text {th }}$ edition. Association of the Official Analytical Chemists, Washington D.C, USA.

AOAC (2003), Association of Official Analytical Chemists, AOAC official method. Fatty acids (free) in crude and refined oils. Official methods of analysis of AOAC international. Washington, DC

Chakrabarty, M. M. 2003, Chemistry and Technology of Oils and Fats. Volume I Ist Edition. Int. J. of Agricu. Inn. and Res. 5(5), 2319-1473

Koh-Banerjee P, Chu NF, Spiegelman D, Rosner B, Colditz G, Willett W, Rimm E., 2003, Prospective study of the association of changes in dietary intake, physical activity, alcohol consumption, and smoking with 9-y gain in waist circumference among 16587 US men. Am J Clin Nutr., 78(4):719-27.

Piotr K, Eliza G. and Boleslaw K, 2008, Changes in the acid value of butter during storage at different temperatures as assessed by standard methods or by FTIR spectroscopy, Am. J. Food Technol, 3(3):154-163.

Priyanka Tangariya, Anushriya Sahoo, Pratima Awasthi and Anupama Pandey, 2018, Quality analysis of composite flour and its effectiveness for Chapatti formulation. J. of Pharmaco and Phytochem, 7(4): 1013-1019

Shaila kurahatti, 2010, Formulation of little millet (Panicum miliare) based composite mix and its quality evaluation, Thesis, University Of Agricultural Sciences, Dharwad - 580005

Shobha, Prasanna Kumar, P. and S. 2011, Effect of Antioxidant on the Shelf Life of Quality Protein Maize Flour 1(3): 129140.

Slavin JL. 2005, Dietary fiber and body weight. Nutrition. 21(3): 411-418.

Sloan AE. 2006. The top ten functional food trends. Food technol., 60(4): 22-40.

Tate, R. L., 1995, Soil Microbiology, John Wiley and Sons, New York.

Thiam, 1977, Contribution to the study of the biochemical phenomena of millet and sorghum flour determination. In Tropical Products Institute Conference Papers, Institut Technologie Alimentaire.

Varsha. R. and Aruna Narayanan, 2017, Storage stability of biofortified pearl millet flour

\section{How to cite this article:}

Geetha, K., Geetha M. Yankanchi and Netravati Hiremath. 2019. Microbial Quality and Storage Stability of Millet Based High Fiber Food Mix. Int.J.Curr.Microbiol.App.Sci. 8(07): 53-57. doi: https://doi.org/10.20546/ijcmas.2019.807.007 